\title{
Buoyancy Regulation in a Strain of Aphanizomenon flos-aquae (Cyanophyceae): the Importance of Carbohydrate Accumulation and Gas Vesicle Collapse
}

\author{
By JACCO KROMKAMP, ${ }^{1 *}$ ALLAN KONOPKA ${ }^{2}$ AND LUUC R. MUR ${ }^{1}$ \\ ${ }^{1}$ Laboratory of Microbiology, University of Amsterdam, Nieuwe Achtergracht 127, \\ 1018 WS Amsterdam, The Netherlands \\ ${ }^{2}$ Department of Biological Sciences, Purdue University, West Lafayette, Indiana 47907, USA
}

(Received 21 November 1985; revised 19 February 1986)

\begin{abstract}
Buoyancy regulation in light-limited continuous cultures of Aphanizomenon flos-aquae was studied. Gas vesicle collapse did not occur during growth under a light-dark cycle. Only cultures with growth rates less than $20 \%$ of the maximal growth rate were positively buoyant. The loss of buoyancy at higher growth rates was due to a lower gas vesicle content in the cells. Carbohydrate accumulation was the main factor which caused buoyancy loss if the cells were shifted from low to high photon flux densities. In these experiments turgor-induced gas vesicle collapse occurred only in cultures adapted to long light periods, and several hours after the cells had lost buoyancy due to ballast increase. The results are discussed in relation to adaptation patterns in photosynthesis and carbon metabolism caused by intermittent light.
\end{abstract}

\section{INTRODUCTION}

A number of planktonic cyanobacteria (blue-green algae) contain microscopic gas-filled cell inclusions, called gas vesicles. These proteinaceous structures can provide buoyancy to a prokaryotic cell if they occur in sufficient quantities (Walsby, 1971, 1978). Previous studies on buoyancy have stressed the role of light: an increase in light intensity often causes a decrease in buoyancy (Dinsdale \& Walsby, 1972; Reynolds \& Walsby, 1975). Some cyanobacteria, e.g. Anabaena spp., have relatively weak gas vesicles, and a turgor pressure rise may be sufficient to collapse some of the vesicles. Based upon this observation a model of buoyancy regulation was proposed by Reynolds \& Walsby (1975). A turgor pressure rise can be caused by production of osmotically active photosynthetic metabolites (Grant \& Walsby, 1977) and by light-stimulated potassium uptake (Allison \& Walsby, 1981). As a turgor pressure rise coincided with a loss of buoyancy in natural populations of Aphanizomenon flos-aquae (Konopka et al., 1978) and Oscillatoria rubescens (Konopka, 1982) the model seems to account for the behaviour of some field populations. Some cyanobacteria, however, have gas vesicles which are too strong to be collapsed by turgor pressure, e.g. Microcystis aeruginosa and a red strain of Oscillatoria agardhii; in these cyanobacteria the buoyant densities increased due to carbohydrate accumulation in the light (Kromkamp \& Mur, 1984; Thomas \& Walsby, 1975; Utkilen et al., 1985).

The three mechanisms of losing buoyancy, namely gas vesicle collapse, storage of heavy polymers (ballast) inside the cell, and regulation of gas vesicle synthesis, were recently reviewed by Konopka (1984). His model predicts that if the rate of energy generation balances the capacity for growth, the organisms will be positively buoyant, and if the rate of energy production is larger than the growth capacity (i.e. during nutrient-limited growth or during growth at saturating photon flux densities) they will be negatively buoyant. Implicit in this model, however, is the idea that an energy-limited natural population can approach the maximal

Abbreviations: $\mathrm{L}: \mathrm{D}$, light : dark; $\mathrm{RGV}$, relative gas vesicle content. 
growth rate $\left(\mu_{\max }\right)$ with increasing light intensities, but will never reach it, because ballast will increase and the gas vesicle content will decrease. The regulation of gas vesicle synthesis will determine how far the organisms will sink and how close the growth rate will come to $\mu_{\max }$. However, no studies have been done on the relationship between growth rate and gas vesicle content. In this paper we report the buoyancy responses of Aphanizomenon flos-aquae grown in light-limited continuous cultures.

\section{METHODS}

Organism and cultivation. Aphanizomenon flos-aquae PCC 7905 was isolated from the Brielse Meer (The Netherlands) and kindly supplied by Dr F. I. Kappers (RIVM, Leidschendam, The Netherlands). The organism is kept in the culture collection of the Laboratory of Microbiology, University of Amsterdam.

Cultures were grown in 2-I chemostat vessels in a nutrient-sufficient mineral medium (van Liere \& Mur, 1978) with different light:dark (L:D) cycles of $24 \mathrm{~h}$. The $\mathrm{pH}$ was $8 \cdot 2 \pm 0 \cdot 2$, the temperature was maintained at $20 \pm$ $1{ }^{\circ} \mathrm{C}$, and aeration $\left(601 \mathrm{~h}^{-1}\right)$ provided adequate mixing and prevented $\mathrm{CO}_{2}$ limitation. The continuous cultures were operated as turbidostats $\left(\mathrm{OD}_{750} 0 \cdot 15-0 \cdot 25\right)$. Illumination was provided by warm-white circular fluorescent tubes (Philips TLE 32W/colour 33 or TLEM $40 \mathrm{~W} / 33$ ). Light was measured according to van Liere et al. (1978). During a light pulse light was provided by a bank of fluorescent lamps (Philips TL 40W/33) or a slide projector. During incubation the samples were gently bubbled with air. The average photon flux density, $I$, was calculated according to the equation $I=\left(I_{0}-I_{\mathrm{d}}\right) /\left(\ln I_{0}-\ln I_{\mathrm{d}}\right)$, where $I_{0}$ is the incident photon flux density and $I_{\mathrm{d}}$ is the photon flux density leaving the culture (van Liere \& Walsby, 1982).

Measurements and analyses. Turgor pressure was measured according to Walsby (1973). The relative gas vesicle content (RGV) was calculated as the pressure-sensitive turbidity (recorded in $\mu \mathrm{V}$ ) per mg cell protein (Kromkamp \& Mur, 1984).

Buoyant densities $\left(\mathrm{g} \mathrm{ml}^{-1}\right.$ ) were determined in Percoll gradients (Pharmacia) with the same osmotic pressure as the growth medium, according to Kromkamp \& Mur (1984).

Floating and sinking filaments were counted under the microscope in Sedgwick-Rafter cells according to Walsby \& Booker (1980). Carbohydrate was determined on freeze-dried samples by the anthrone method with Dglucose as standard, and protein was determined with the Folin reagent using bovine serum albumin as standard, both according to Herbert et al. (1971). Ballast was calculated as the weight of the constituent minus the weight of water displaced by that constituent, assuming densities of $1.6 \mathrm{~g} \mathrm{ml}^{-1}$ and $1.3 \mathrm{~g} \mathrm{ml}^{-1}$ for carbohydrate and protein, respectively (Oliver \& Walsby, 1984).

Photosynthetic rate was determined as a function of photon flux density using the initial rates of oxygen evolution measured with a Clark-type oxygen electrode (Yellow Springs, YSI 5331) according to Post et al. (1986).

\section{RESULTS.}

As growth rate increased from 0.005 to $0.031 \mathrm{~h}^{-1}$, the $\mathrm{RGV}$ of steady-state cultures grown under a $16 \mathrm{~h}: 8 \mathrm{~h}$ light : dark cycle (16L :8D) decreased nearly threefold (Fig. 1). Energy-limited cultures grown at a rate of $0.015 \mathrm{~h}^{-1}$ were obtained in three ways: (a) $16 \mathrm{~L}: 8 \mathrm{D}$ with an average photon flux density $(I)$ of $33 \mu \mathrm{mol} \mathrm{m}^{-2} \mathrm{~s}^{-1}$, (b) $12 \mathrm{~L}: 12 \mathrm{D}$ with $I=43 \mu \mathrm{mol} \mathrm{m}^{-2} \mathrm{~s}^{-1}$ and $(c)$ $8 \mathrm{~L}: 16 \mathrm{D}$ with $I=110 \mu \mathrm{mol} \mathrm{m}^{-2} \mathrm{~s}^{-1}$. The RGV of these three cultures was the same despite the different photon flux densities to which they were exposed. It is clear that photon flux density itself did not determine the RGV; it seems more likely that it was determined by the energylimited growth rate.

The relative net synthesis rate of gas vesicles can be calculated as the product of RGV and the steady-state growth rate (Fig. 2). The value calculated in this way gives an estimate of the net synthesis rate; the actual synthesis rate will be larger by a factor equal to the turnover rate of the gas vesicles. The gas vesicle synthesis rate was not constant but increased linearly with growth rate. However, with a sixfold increase in specific growth rate the gas vesicle synthesis rate increased only twofold. Thus the rate of total protein synthesis increased more rapidly than synthesis of gas vesicles with increasing photon flux densities. This means that the cells regulated their gas vesicle synthesis rate; it also explains why the RGV decreased as growth rate increased.

An alternative explanation for the decreases in RGV is that although gas vesicle synthesis rates in all cultures are similar, some gas vesicles assembled in the cultures growing at high rates are collapsed by turgor pressure. To test this hypothesis, the amount of external pressure 


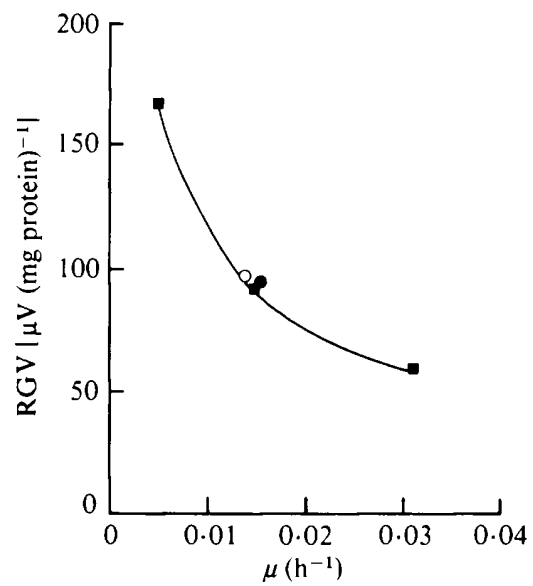

Fig. 1

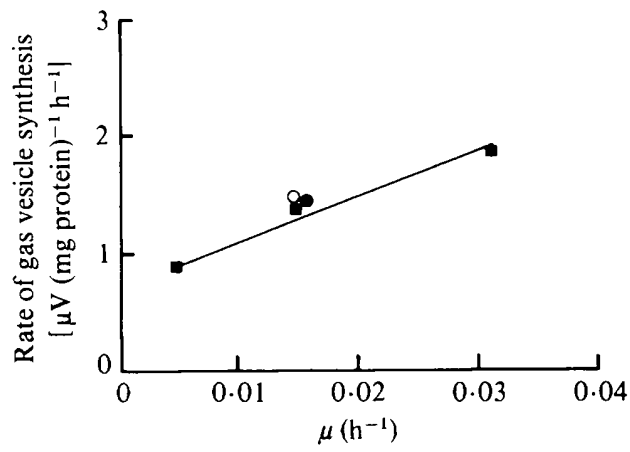

Fig. 2

Fig. 1. RGV of Aphanizomenon flos-aquae as a function of growth rate. $, 16 \mathrm{~L}: 8 \mathrm{D} ; \mathrm{O}, 12 \mathrm{~L}: 12 \mathrm{D}$; , $8 \mathrm{~L}: 16 \mathrm{D}$.

Fig. 2. Rate of synthesis of gas vesicles of Aphanizomenon flos-aquae as a function of growth rate. 口, $16 \mathrm{~L}: 8 \mathrm{D} ; \mathrm{O}, 12 \mathrm{~L}: 12 \mathrm{D} ; 0,8 \mathrm{~L}: 16 \mathrm{D}$.

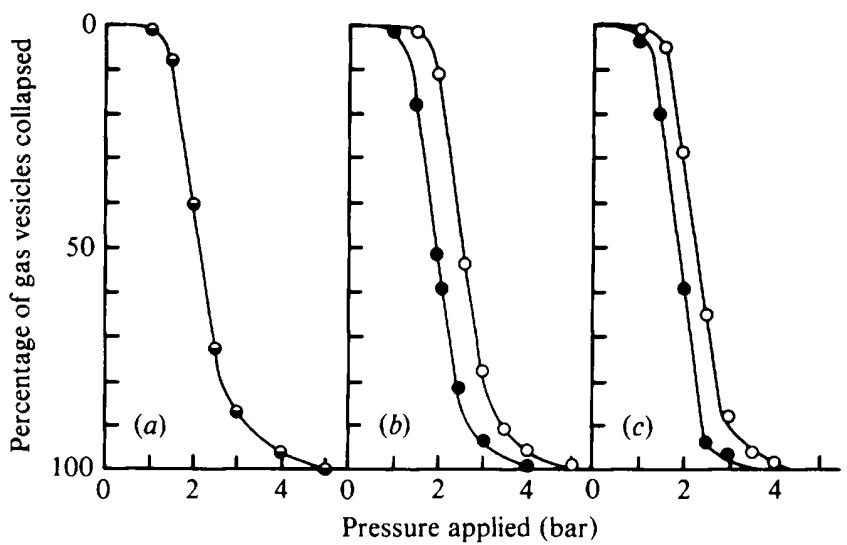

Fig. 3. Pressure-collapse curves of Aphanizomenon flos-aquae gas vesicles after growth of cells at: $(a)$ 16L:8D; $\mu=0.005 \mathrm{~h}^{-1} ;(b) 16 \mathrm{~L}: 8 \mathrm{D}, \mu=0.015 \mathrm{~h}^{-1} ;(c) 16 \mathrm{~L}: 8 \mathrm{D}, \mu=0.031 \mathrm{~h}^{-1}$. $\mathrm{O}$, Start of light period;, end of light period.

required to collapse gas vesicles in the cells was determined at the beginning and end of the light period for each steady-state culture (Fig. 3). Gas vesicles were not collapsed by turgor pressure. If the turgor pressure had been high enough to collapse the weaker gas vesicles in the cells, additional gas vesicles would have been collapsed as soon as external pressure was applied. However, even at the end of the light period, a pressure of $0.5-1.0$ bar had to be applied before any gas vesicles were collapsed. The tugor pressures at the end of the light period were similar in all three cultures grown on a $16 \mathrm{~L}: 8 \mathrm{D}$ cycle, despite the 14 -fold difference in average photon flux density among these cultures (Table 1). The culture with the lowest growth rate maintained a turgor pressure of 3.7 bar during the dark period, whereas there was a fluctuation of 0.55 bar between the start and the end of the dark period in the culture with a growth rate of $0.015 \mathrm{~h}^{-1}$. Although all these cultures were energy-limited, only that grown at $\mu=0.005 \mathrm{~h}^{-1}$ was positively buoyant (Table 1). More than $90 \%$ of the filaments sank in cultures grown at $0.5 \mu_{\max }$ (i.e. still severely energy-limited), irrespective of the combinations of photon flux densities and photoperiod used to achieve that growth rate. The buoyant densities did not seem to change with growth rate. 


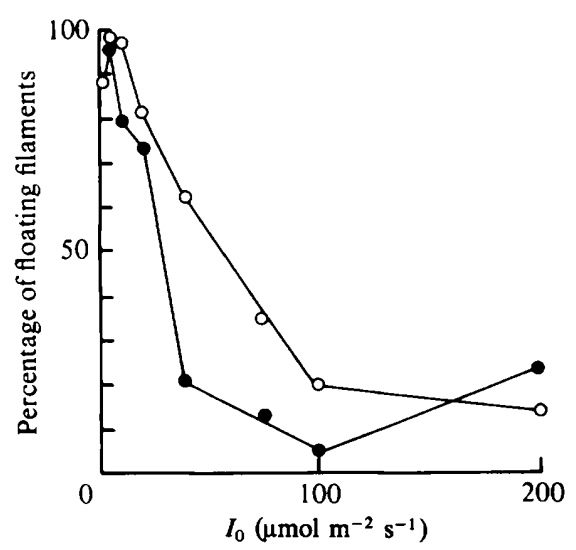

Fig. 4. Loss of buoyancy of Aphanizomenon fios-aquae in a $16 \mathrm{~L}: 8 \mathrm{D}$ culture $\left(\mu=0.005 \cdot \mathrm{h}^{-1}\right)$ incubated at the start of the light period at different incident photon flux densities $\left(I_{0}\right)$ for $2 \mathrm{~h}(O)$ or $5 \mathrm{~h}(O)$.

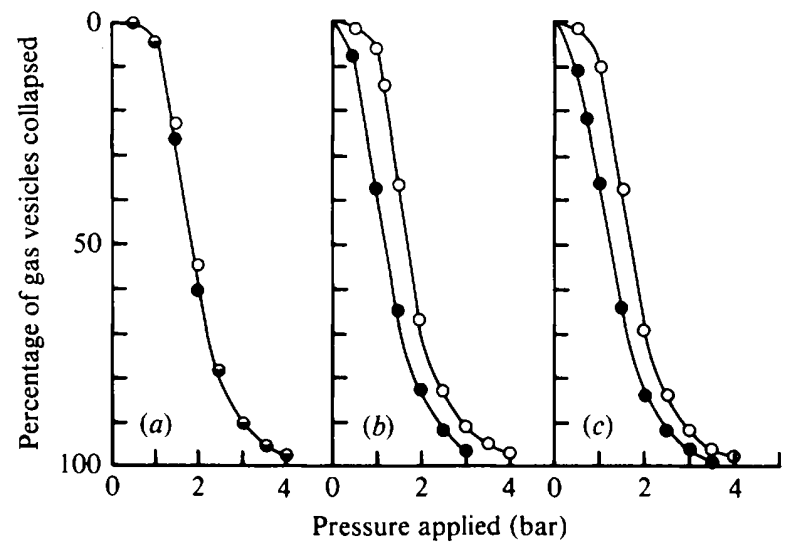

Fig. 5. Pressure-collapse curves of Aphanizomenon flos-aquae gas vesicles in turgid cells from a $16 \mathrm{~L}: 8 \mathrm{D}$ culture $\left(\mu=0.005 \mathrm{~h}^{-1}\right)$ incubated at incident photon flux densities of $(a) 75,(b) 100$ or $(c)$ $200 \mu \mathrm{mol} \mathrm{m}^{-2} \mathrm{~s}^{-1}$ for $2 \mathrm{~h}(\mathrm{O})$ or $5 \mathrm{~h}(\mathrm{O})$.

Table 1. Turgor pressure, percentage of floating flaments, buoyant density and average photon flux density of Aphanizomenon flos-aquae cultures at the start $(t=0)$ or end $(t=16)$ of $a$ $16 L: 8 D$ cycle

\begin{tabular}{|c|c|c|c|c|c|c|}
\hline \multirow{2}{*}{$\begin{array}{c}\mu \\
\left(\mathrm{h}^{-1}\right)\end{array}$} & \multicolumn{2}{|c|}{$\begin{array}{c}\begin{array}{c}\text { Turgor } \\
\text { pressure (bar) }\end{array} \\
.\end{array}$} & \multicolumn{2}{|c|}{$\begin{array}{c}\text { Floating } \\
\text { filaments }(\%)\end{array}$} & \multirow{2}{*}{$\begin{array}{c}\text { Buoyant } \\
\text { density } \\
\left(\mathrm{g} \mathrm{ml}^{-1}\right) \\
t=0\end{array}$} & \multirow{2}{*}{$\left(\mu \mathrm{mol} \mathrm{\textrm {m } ^ { - 2 } \mathrm { s } ^ { - 1 } )}\right.$} \\
\hline & $t=0$ & $t=16$ & $t=0$ & $t=16$ & & \\
\hline 0.005 & $3 \cdot 70$ & $3 \cdot 70$ & 85 & 80 & 1.050 & 10 \\
\hline 0.015 & 3.25 & 3.80 & 6 & 0 & 1.051 & 44 \\
\hline 0.031 & $3 \cdot 60$ & 3.85 & 0 & 0 & - & 140 \\
\hline
\end{tabular}

The above measurements were all made on steady-state cultures, which were adapted to a specific photoperiod and photon flux density. To determine the effect of increases in photon flux density, samples were taken from the buoyant culture $\left(\mu=0.005 \mathrm{~h}^{-1}\right)$ at the beginning of the daily photoperiod and exposed to different photon flux densities for 2 or $5 \mathrm{~h}$. Buoyancy loss occurred at photon flux densities $>50 \mu \mathrm{mol} \mathrm{m}^{-2} \mathrm{~s}^{-1}$ after $2 \mathrm{~h}$ or $>30 \mu \mathrm{mol} \mathrm{m}^{-2} \mathrm{~s}^{-1}$ after $5 \mathrm{~h}$ incubation (Fig. 4), whereas gas vesicle collapse only occurred after $5 \mathrm{~h}$ at 100 or $200 \mu \mathrm{mol} \mathrm{m}^{-1} \mathrm{~s}^{-1}$ (Fig. 5), long after the filaments had begun to sink. Therefore, the collapse of 

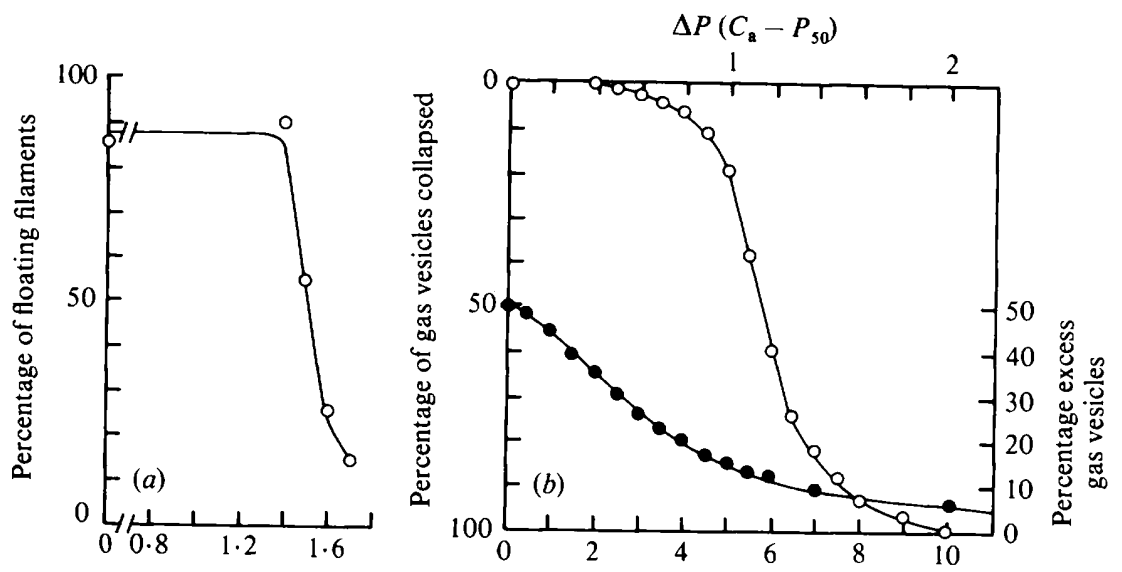

Pressure applied (bar)

Fig. 6. (a) Percentage of Aphanizomenon flos-aquae filaments floating after small increments of pressure. (b) Strength distribution of isolated gas vesicles $(O)$. The pressure difference $(\Delta P)$, calculated from the apparent median critical pressure $\left(C_{\mathrm{a}}\right)$ and the pressure needed to give $50 \%$ floating filaments $\left(P_{50}\right)$, can be used to determine the percentage of excess gas vesicles. From the strength distribution of isolated gas vesicles, the corresponding percentage of collapsed gas vesicles is determined at different values of $\triangle P$ : e.g. at a $\Delta P$ of 1 bar, $15 \%$ of the vesicles are collapsed. From these $\Delta P$ values a graph is constructed showing the relationship between $\Delta P$ and the amount of gas vesicles that have to be collapsed to give a $50 \%$ floating culture (O). These amounts are equivalent to the percentage excess gas vesicles.

Table 2. Increases in protein and carbohydrate ballast in Aphanizomenon flos-aquae taken from a $10 L: 8 D$ culture, $\mu=0.005 \mathrm{~h}^{-1}$, and incubated at different photon flux densities $(I)$

$$
\text { for } 2 \text { or } 5 h
$$

The initial ballast content (carbohydrate plus protein) was $13 \cdot 3 \mathrm{mg}$.

\begin{tabular}{|c|c|c|c|c|c|c|}
\hline \multirow[b]{3}{*}{$\begin{array}{c}I \\
\left(\mu \mathrm{mol} \mathrm{m} \mathrm{m}^{-2} \mathrm{~s}^{-1}\right)\end{array}$} & \multicolumn{6}{|c|}{ Increase in ballast $\left(\mathrm{mg} \mathrm{1}^{-1}\right)$} \\
\hline & \multicolumn{3}{|c|}{$2 \mathrm{~h}$} & \multicolumn{3}{|c|}{$5 \mathrm{~h}$} \\
\hline & Protein & Carbohydrate & Sum & Protein & Carbohydrate & Sum \\
\hline 0 & 0.0 & $0 \cdot 0$ & $0 \cdot 0$ & 1.6 & $0 \cdot 0$ & 1.5 \\
\hline 5 & $1 \cdot 3$ & 0.3 & 1.6 & 1.6 & 0.4 & 1.9 \\
\hline 10 & $1 \cdot 2$ & $0 \cdot 3$ & 1.5 & $1 \cdot 6$ & 0.8 & $2 \cdot 4$ \\
\hline 20 & $1 \cdot 0$ & 1.6 & $2 \cdot 6$ & $2 \cdot 0$ & $2 \cdot 5$ & $4 \cdot 5$ \\
\hline 40 & $1 \cdot 1$ & $3 \cdot 1$ & $4 \cdot 2$ & 1.9 & $6 \cdot 8$ & $8 \cdot 7$ \\
\hline 75 & $1 \cdot 3$ & $2 \cdot 6$ & $4 \cdot 0$ & $1 \cdot 8$ & $4 \cdot 7$ & 6.4 \\
\hline 100 & 1.8 & 4.5 & 6.4 & $2 \cdot 0$ & 8.4 & $10 \cdot 3$ \\
\hline 200 & $1 \cdot 3$ & 4.5 & $5 \cdot 7$ & $2 \cdot 0$ & 3.7 & $5 \cdot 6$ \\
\hline
\end{tabular}

gas vesicles by turgor pressure was not the primary cause of buoyancy loss in Aphanizomenon flosaquae shifted to higher photon flux densities. The alternative explanation for buoyancy loss is the accumulation of 'heavy' molecules (ballast) in the cell which compensate for the buoyancy provided by gas vesicles. To determine how much ballast would be necessary to overcome gas vesicle buoyancy, the proportion of gas vesicles in excess of those needed to provide neutral buoyancy was determined. Small increments of pressure were applied to samples of the cultures in order to collapse different amounts of gas vesicles, and the buoyancy of filaments in these samples was then measured (Fig. $6 a$ ); from this the pressure at which $50 \%$ of the filaments floated $\left(P_{50}\right)$ was determined. From the $P_{50}$ value and the pressure needed to collapse $50 \%$ of the gas vesicles in the culture (median apparent critical pressure, $C_{\mathrm{a}}$ ) we calculated that $23 \%$ of the vesicles had to be collapsed to produce neutral buoyancy in this culture (Fig. 6b). 


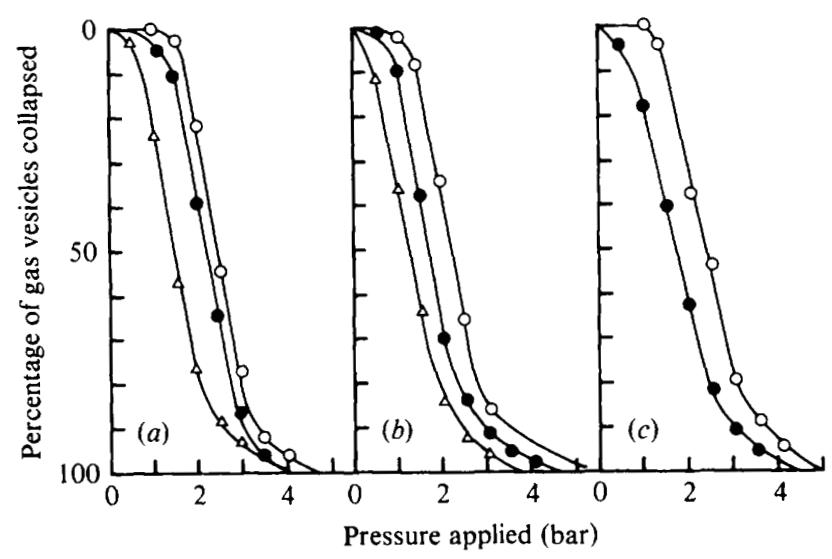

Fig. 7. Pressure-collapse curves for Aphanizomenon flos-aquae gas vesicles in turgid cells from cultures grown at $8 \mathrm{~L}: 16 \mathrm{D}(\mathrm{a}), 16 \mathrm{~L}: 8 \mathrm{D}(\mathrm{b})$, and $24 \mathrm{~L}: 0 \mathrm{D}(\mathrm{c})$, made at the start $(\mathrm{O})$, and after $2 \mathrm{~h}(O)$ and $5 \mathrm{~h}(\triangle)$ at an average photon flux density of $200 \mu \mathrm{mol} \mathrm{m} \mathrm{m}^{-2} \mathrm{~s}^{-1}$.

Table 3. Turgor changes, rates of photosynthesis and carbohydrate accumulation at saturating photon flux density and the percentage of fixed $\mathrm{CO}_{2}$ stored as carbohydrate in cultures of Aphanizomenon flos-aquae grown under three different $L: D$ cycles $\left(\mu=0.005 h^{-1}\right)$

\begin{tabular}{|c|c|c|c|c|}
\hline $\begin{array}{l}\mathrm{L}: \mathrm{D} \\
\text { cycle }\end{array}$ & $P_{\max }^{N^{*}}$ & $v_{\mathrm{CH}_{2} \mathrm{O}^{\dagger}}$ & $\begin{array}{c}\text { Fixed } \mathrm{CO}_{2} \text { stored } \\
\text { as carbohydrate } \\
(\%) \ddagger\end{array}$ & $\begin{array}{l}\text { Turgor increase } \\
\text { after } 2 \mathrm{~h} \\
\text { (bar) }\end{array}$ \\
\hline $\begin{array}{l}8 \mathrm{~L}: 16 \mathrm{D} \\
16 \mathrm{~L}: 8 \mathrm{D} \\
24 \mathrm{~L}: 0 \mathrm{D}\end{array}$ & $\begin{array}{l}0 \cdot 14 \\
0 \cdot 30 \\
0 \cdot 16\end{array}$ & $\begin{array}{l}0.094 \\
0.163 \\
0.073\end{array}$ & $\begin{array}{l}73 \\
58 \\
49\end{array}$ & $\begin{array}{l}0 \cdot 2 \\
0 \cdot 5 \\
0 \cdot 7\end{array}$ \\
\hline
\end{tabular}

* Net maximal photosynthetic capacity [mg $\mathrm{O}_{2}(\mathrm{mg} \text { protein })^{-1} \mathrm{~h}^{-1}$ ].

+ Carbohydrate accumulation rate at saturating photon flux density for photosynthesis [ $\mathrm{mg} \mathrm{CH}_{2} \mathrm{O}$ (mg protein) ${ }^{-1}$ $\mathrm{h}^{-1} \mathrm{]}$.

$\ddagger$ Assuming that $1 \mathrm{mg} \mathrm{O} \mathrm{O}_{2} \equiv 0.92 \mathrm{mg} \mathrm{CH} \mathrm{CH}_{2} \mathrm{O}$.

Polysaccharide and protein are the major ballast components in cyanobacteria (Oliver \& Walsby, 1984). At the beginning of the experiment, the total ballast due to protein and carbohydrate was $13.3 \mathrm{mg} \mathrm{l}^{-1}$. However, to counterbalance the 'excess gas vesicles' $(23 \%$ of the total), ballast would have to be $[100 /(100-23)] \times 13.3=17.2 \mathrm{mg}$. Thus the cells would have to form an additional $4 \mathrm{mg}$ ballast to sink. Table 2 lists the measured increases in protein and polysaccharide content of the cultures shifted to different photon flux densities, together with the calculated ballast increase. Comparison with Fig. 4 indicates that in nearly all conditions where the ballast increase was less than $4 \mathrm{mg}$, most filaments remained buoyant, whereas when the ballast increase exceeded $4 \mathrm{mg}$, most of the filaments sank. Thus in this strain of Aphanizomenon flos-aquae, which has relatively weak gas vesicles with a median critical pressure of 5.8 bar, rapid changes in buoyancy were mediated by increases in ballast (primarily due to polysaccharides) rather than by turgor-induced collapse of gas vesicles. Because this conclusion differed from that of other workers (Dinsdale \& Walsby, 1972; Oliver \& Walsby, 1984), we determined whether turgor-induced gas vesicle collapse would occur more rapidly in an energylimited continuous culture with an $8 \mathrm{~L}: 16 \mathrm{D}$ cycle and a batch culture adapted to continuous light, both with the same low growth rate (approx. $0.005 \mathrm{~h}^{-1}$ ). When these cultures were shifted to high photon flux densities, the one adapted to continuous light showed gas vesicle collapse after $2 \mathrm{~h}$, whereas the 8L:16D culture showed no gas vesicle collapse (Fig. 7). It is therefore concluded that the importance of gas vesicle collapse in buoyancy regulation depends upon the physiological state of the cells. Because carbon fixation and polysaccharide synthesis are 
important in buoyancy regulation, we determined what proportion of the fixed $\mathrm{CO}_{2}$ was converted to stored carbohydrate. If $6 \mathrm{CO}_{2}+6 \mathrm{H}_{2} \mathrm{O}$ is converted to $\mathrm{C}_{6} \mathrm{H}_{12} \mathrm{O}_{6}+6 \mathrm{O}_{2}$, then as a theoretical maximum, $1 \mathrm{mg} \mathrm{O}$ is equivalent to $0.92 \mathrm{mg} \mathrm{CH}_{2} \mathrm{O}$. As shown in Table 3, cells adapted to shorter light periods did convert more fixed $\mathrm{CO}_{2}$ into polyglucose and showed a smaller increase in turgor than cells adapted to longer light periods.

\section{DISCUSSION}

\section{Steady-state growth responses}

The steady-state data clearly showed that the RGV of the cells varied as a function of energylimited growth rate. This was not directly due to light intensity, because the three cultures grown at $0.5 \mu_{\max }$ but adapted to different photon flux densities by varying the photoperiod had the same RGV. The lower RGV of the cells at higher growth rates was not caused by turgor-induced gas vesicle collapse. Thus the cells regulated their gas vesicle synthesis rate. The gas vesicle assembly rate was not constant, but increased with growth rate, although to a lesser extent than the synthesis of cell proteins. This means that if growth accelerates the gas vesicle content will decrease and the cyanobacteria lose their buoyancy.

The buoyant culture at $\mu=0.005 \mathrm{~h}^{-1}$ contained $23 \%$ 'excess gas vesicles'. Thomas \& Walsby (1985) found that $18-52 \%$ of the vesicles had to be collapsed in their Microcystis strain to obtain neutrally buoyant cells. Energy-limited cultures of Microcystis aeruginosa AK 1 were buoyant at all growth rates below $\mu_{\max }$ (Kromkamp et al., 1985) and the excess gas vesicle content was 22$42 \%$. The strain of Aphanizomenon flos-aquae we used, however, floated only if the energylimited growth rate was below $0 \cdot 2 \mu_{\max }$. So even at half-maximal growth rates, when light limitation was still severe, the filaments sank. The advantage of this response is not apparent, but on the other hand it is uncertain whether maximal growth rates occur in nature. If energylimited organisms with this type of buoyancy regulation are positively buoyant in the natural environment, it is likely that they grow at low rates.

\section{Transient-state experiments}

Oliver \& Walsby (1984) concluded that buoyancy loss in Anabaena flos-aquae after a transition from low to high photon flux densities was primarily due to a decrease in the gas vesicle content of the cells, and that gas vesicle collapse was the most likely mechanism of buoyancy regulation for species with 'weak gas vesicles'. Although the Aphanizomenon flos-aquae strain we used had gas vesicles of similar strength to those of Anabaena flos-aquae, turgor-induced gas vesicle collapse was not important in our studies. If a buoyant culture was shifted to higher incident photon flux densities, we found that $(a)$ buoyancy was lost even when no gas vesicle collapse occurred, and $(b)$ even if collapse by turgor occurred after $5 \mathrm{~h}$ incubation, buoyancy was lost in $2 \mathrm{~h}$. All the results could be explained by an increase in the content of ballast, of which polysaccharide was the most important component.

The differences between our results and those of Oliver \& Walsby (1984) may be due to differences between the two strains and/or to the time at which the cultures were analysed after the transfer from low to high photon flux densities. However, we think that the differences with regard to turgor-induced gas vesicle collapse reflect the physiological state of the cyanobacteria; that is, the adaptation pattern to photoperiod length and photon flux density. As the photoperiod decreases, the cells adapt by accelerating carbohydrate storage, enabling more of the fixed $\mathrm{CO}_{2}$ to be stored as polysaccharide during short photoperiods (Fay \& Smith, 1980; Loogman, 1982).

This stored carbon serves as an energy and carbon source during dark growth, and indeed cyanobacteria show high yields (protein formed/polyglucose used) with short photoperiods (Loogman, 1982; Post et al., 1985; J. Kromkamp \& A. Konopka, unpublished results). Table 3 illustrates that cultures grown with shorter photoperiods store more $\mathrm{CO}_{2}$ as osmotically inactive polyglucose than those grown in continuous light. Part of the fixed $\mathrm{CO}_{2}$ also goes into protein synthesis, although the amount of protein synthesized during a pulse is small compared to the carbohydrate accumulated (Kromkamp \& Mur, 1984; Kromkamp et al., 1985; Konopka et al., 
1985; Thomas \& Walsby, 1985; Table 2). Because a smaller proportion of the fixed $\mathrm{CO}_{2}$ and energy is stored as polyglucose in cultures adapted to long photoperiods, a larger increase in turgor pressure can occur (Table 3), due to the accumulation of photosynthetic metabolities (Grant \& Walsby, 1977), and perhaps by inorganic ions transported by light-driven pumps (Allison \& Walsby. 1981).

Our results show all three of the methods for regulation of buoyancy: ballast accumulation, regulation of gas vesicle synthesis and turgor-induced gas vesicle collapse. The latter seems to play a minor role in natural systems, because long photoperiods do not occur, although care has to be taken in extrapolating our results to other species, since gas vesicle collapse by turgor has been shown for a natural population of Aphanizomenon (Konopka et al., 1978). However, because of the $7 \mathrm{~h}$ incubation period used in the latter study it is not possible to tell whether buoyancy loss was primarily caused by ballast increase or gas vesicle collapse. Regulation of gas vesicle synthesis appears to be a long-term process. Several generation times were required to reassemble all the gas vesicles in cultures of the heterotrophic bacterium Ancylobacter aquaticus (formerly Microcyclus aquaticus; Raj, 1983) in which the vesicles were collapsed (Konopka et al., 1975). Thus this mechanism is not likely to be responsible for rapid diurnal changes in buoyancy. Ballast changes, caused by polysaccharide storage in the light and utilization in the dark, seem to be the most plausible mechanism for diurnal buoyancy changes. Variations in carbohydrate content have been shown to be responsible for diurnal changes in buoyancy in natural populations of Oscillatoria (Utkilen et al., 1985); however, the gas vesicles of this cyanobacterium are too strong to be collapsed by turgor pressure. Based upon the results of this paper, ballast accumulation should also be the primary mechanism of buoyancy regulation in species with weak gas vesicles, but this hypothesis requires experimental verification.

We thank Udo van Hes for making the pressure nephelometer, Anneke van Egmond for technical assistance, and Jerien Braakman-de Vriend and Truus Smit for typing the manuscript.

\section{REFERENCES}

Allison, E. M. \& Walsby, A. E. (1981). The role of potassium in the control of turgor pressure in a gasvacuolate blue-green alga. Journal of Experimental Botany 32, 241-249.

Dinsdale, M. T. \& WalsBy, A. E. (1972). The interrelations of cell turgor pressure, gas-vacuolation, and buoyancy in a blue-green alga. Journal of Experimental Botany 23, 561-570.

Foy, R. H. \& SMITH, R. V. (1980). The role of carbohydrate accumulation in the growth of planktonic Oscillatoria species. British Phycological Journal 15, $139-150$.

Grant, N. G. \& Walsby, A. E. (1977). The contribution of photosynthate to turgor pressure rise in the planktonic blue-green alga Anabaena flos-aquae. Journal of Experimental Botany 28, 409415.

Herbert, D., Phipps, P. J. \& Strange, R. W. (1971). Chemical analysis of microbial cells. Methods in Microbiology 5B, 209-344.

KonOPKA, A. (1982). Buouancy regulation and vertical migration by Oscillatoria rubescens in Crooked Lake, Indiana. British Phycological Journal 17, 427-442.

KoNOPKA, A., (1984). Effect of light-nutrient interactions on buoyancy regulation by planktonic cyanobacteria. In Current Perspectives in Microbial Ecology, pp. 41-48. Edited by M. J. Klug \& C. A. Reddy. Washington, DC: American Society for Microbiology.

Konopka, A. E., Staley, J. T. \& Lara, J. C. (1975). Gas vesicle assembly in Microcyclus aquaticus. Journal of Bacteriology 122, 1301-1309.
Konopka, A., Brock, T. D. \& Walsby, A. E. (1978). Buoyancy regulation by planktonic blue-green algae in Lake Mendota, Wisconsin, Archiv für Hydrobiologie 83, 524-537.

Konopka, A., Kromkamp, J. \& MUR, L. R. (1985). The role of gas vesicle and polysaccharide content upon the buoyancy of Aphanizomenon flos-aquae. Abstracts of the Fifth International Symposium on Photosynthetic Prokaryotes, Zurich, Switzerland, p. 188.

Kromkamp, J. C. \& MuR, L. R. (1984). Buoyant density changes in the cyanobacterium Microcystis aeruginosa due to changes in the cellular carbohydrate content. FEMS Microbiology Letters 25, 105109.

Kromkamp, J. C., Konopka, A. \& Mur, L. R. (1985). Buoyancy regulation in energy or phosphate limited Microcystis aeruginosa. Abstracts of the Fifth International Symposoium on Photosynthetic Prokaryotes, Zurich, Switzerland, p. 186.

VAN LIERE, L. \& MUR, L. R. (1978). Light-limited cultures of the blue-green alga Oscillatoria agardhii. Mitteilungen der internationale Vereinigung für theoretische und angewandte Limnologie 21, 158-167.

VAN LIERE, L. \& WALSBY, A. E. (1982). Interaction of cyanobacteria with light. In The Biology of Cyanobacteria, pp. 9-45. Edited by N. G. Carr \& B. A. Whitton. Oxford: Blackwell Scientific Publications. VAN Liere, L., LoOgman, J. G. \& MUR, L. R. (1978). Measuring light-irradiance in cultures of phototrophic microorganisms. FEMS Microbiology Letters 3, 161-164. 
LoOGMAN, J. G. (1982). Influence of photoperiodicity on algal growth kinetics. PhD thesis, University of Amsterdam.

Oliver, R. L. \& W ALSBY, A. E. (1984). Direct evidence for the role of light-mediated gas-vesicle collapse in the buoyancy regulation of Anabaena flos-aquae (cyanobacteria). Limnology and Oceanography 29, 879-886.

Post, A. F., Loogman, J. G. \& MuR, L. R. (1985). Regulation of growth and photosynthesis by Oscillatoria agardhii grown with a light/dark cycle. FEMS Microbiology Ecology 31, 97-102.

Post, A. F., Falkowski, P. G., Dubinsky, Z. \& van HES, U. M. (1986). A complete system for the measurement of photosynthetic characteristics of phytoplankton based on the oxygen electrode technique. Limnology and Oceanography (in the Press).

RAJ, A. D. (1983). Proposal of Ancylobacter, gen. nov., as a substitute for the bacterial genus Microcyclus Orskov 1928. International Journal of Systematic Bacteriology 33, 397-398.

ReYNolds, C. S. \& WalsBy, A. E. (1975). Waterblooms. Biological Reviews 50, 437-481.
Thomas, R. H. \& WalsBy, A. E. (1985). Buoyancy regulation in a strain of Microcystis. Journal of General Microbiology 131, 799-809.

Utkilen, H. C., Oliver, R. L. \& Walsby, A. E. (1985). Buoyancy regulation in a red Oscillatoria unable to collapse gas vacuoles by turgor pressure. Archiv für Hydrobiologie 102, 319-329.

WALSBY, A. E.(1971). The pressure relationships of gas vacuoles. Proceedings of the Royal Society B178, 301326.

WALSBY, A. E. (1973). A portable apparatus for measuring relative gas vacuolation, the strength of gas vacuoles, and turgor pressure in planktonic bluegreen algae and bacteria. Limnology and Oceanography 18, 653-658.

WALSBY, A. E. (1978). The gas vesicles of aquatic prokaryotes. Symposia of the Society for General Microbiology 28, 327-358.

WalsbY; A. E. \& BoOKer, M. J. (1980). Changes in buoyancy of a planktonic blue-green alga in response to light intensity. British Phycological Journal 15, 311-319. 